\title{
Temporal variability in dissolved inorganic nitrogen fluxes at the sediment-water interface and related annual budget on a continental shelf (NW Mediterranean)
}

\author{
Lionel DENIS ${ }^{\mathrm{a} *}$, Christian GRENZ ${ }^{\mathrm{b}}$, Élisabeth ALLIOT $^{\mathrm{c}}$, Martine RODIER $^{\mathrm{d}}$ \\ ${ }^{a}$ UPRESA ELICO, station marine de Wimereux, université des sciences et technologies de Lille, 28, avenue Foch, \\ BP 80, 62930 Wimereux, France
}

${ }^{\text {b }}$ UMR LOB 6535, station marine d'Endoume, centre d'océanologie de Marseille, rue de la Batterie-des-Lions, 13007 Marseille, France

${ }^{c}$ UMR DIMAR 6540, station marine d'Endoume, centre d'océanologie de Marseille, rue de la Batterie-des-Lions, 13007 Marseille, France

${ }^{\mathrm{d}}$ Institut de recherche pour le développement, station marine d'Endoume, centre d'océanologie de Marseille, rue de la Batterie-des-Lions, 13007 Marseille, France

Received 20 April 2000; revised 24 October 2000; accepted 25 October 2000

\begin{abstract}
Sediment-water dissolved inorganic nitrogen fluxes were measured monthly between November 1997 and January 1999 at two sites on the continental shelf in the Gulf of Lions. Exchanges of ammonium, nitrate and nitrite were measured using whole core incubations performed in the laboratory at in situ temperature and in the dark. Stations were located on the shelf and near the shelf break. Nitrate release represented the major part of total dissolved inorganic nitrogen fluxes (52-98\%). At station Sofi, nitrate flux doubled from winter-early spring to August (4 to $10 \mu \mathrm{mol} \mathrm{m} \mathrm{m}^{-2} \mathrm{~h}^{-1}$ ). At station $\mathrm{R}$, a large increase $\left(2\right.$ to $14 \mu \mathrm{mol} \mathrm{m}{ }^{-2} \mathrm{~h}^{-1}$ ) was recorded between December 1997 and January 1998, after which flux tended to decrease. Ammonium flux was generally directed out of the sediment, and was lower at station Sofi than at station R. Nitrite flux was always less than $1 \mu \mathrm{mol} \mathrm{m}{ }^{-2} \mathrm{~h}^{-1}$. A large part of the temporal variability observed at station $\mathrm{R}$ could be attributed to the input of organic matter associated with the discharge of the Rhône River. On the contrary, the influence of the Rhône River is limited at station Sofi, and the spring phytoplankton bloom deposition was probably the major cause of temporal variability. Comparisons of total fluxes with diffusive fluxes suggested a high nitrification rate in the upper centimetre of the sediment. Annual dissolved inorganic nitrogen release from sediments, equivalent to $20-34 \%$ of the Rhône River inputs, may contribute 4-8\% of the requirements for primary production in the Gulf of Lions. (C) 2001 Ifremer/CNRS/IRD/Éditions scientifiques et médicales Elsevier SAS
\end{abstract}

Résumé - Variabilité temporelle des flux d'azote inorganique dissous à l'interface eau-sédiment et bilan annuel sur un plateau continental (Méditerranée nord occidentale). Afin de décrire la variabilité temporelle des flux d'azote inorganique dissous sur le plateau continental du golfe du Lion, un suivi mensuel (novembre 1997-janvier 1999) a été effectué à deux stations. Les flux de $\mathrm{NH}_{4}{ }^{+}, \mathrm{NO}_{3}{ }^{-}, \mathrm{NO}_{2}{ }^{-}$ont été mesurés par incubation de carotte. Le flux de nitrate hors

*Correspondence and reprints: fax: +33 321992901.

E-mail address: Lionel.Denis@univ-lille1.fr (L. DENIS).

(C) 2001 Ifremer/CNRS/IRD/Éditions scientifiques et médicales Elsevier SAS. Tous droits réservés 
du sédiment représente la majeure partie des échanges (52-98\%). A la station Sofi, les flux de nitrate ont doublé de la période hiver-début de printemps jusqu'au mois d'août (4 à $10 \mu \mathrm{mol} \mathrm{m}^{-2} \mathrm{~h}^{-1}$ ). Pour la station $\mathrm{R}$, une forte augmentation (2 à $14 \mu \mathrm{mol} \mathrm{m}{ }^{-2} \mathrm{~h}^{-1}$ ) a été enregistrée entre décembre 1997 et janvier 1998, après laquelle les flux ont tendance à diminuer. Les flux d'ammonium sont généralement dirigés vers la colonne d'eau, plus faibles à la station Sofi qu'à la station R. Les flux de nitrite sont toujours inférieurs à $1 \mu \mathrm{mol} \mathrm{m} \mathrm{m}^{-2} \mathrm{~h}^{-1}$. Une large partie de la variabilité temporelle observée à la station $\mathrm{R}$ a pu être attribuée à l'apport de matière organique consécutif à des débits rhodaniens maximaux. Au contraire, l'influence du Rhône à la station Sofi est limitée et la sédimentation de l'efflorescence phytoplanctonique printanière est certainement la cause majeure de la variabilité temporelle. La comparaison des flux totaux avec les flux diffusifs suggère des taux de nitrification élevés dans le centimètre superficiel du sédiment. En se basant sur l'évolution temporelle de ces deux stations, le flux d'azote inorganique dissous en provenance des sédiments, équivalent à 20-34\% des apports rhodaniens, pourrait fournir de 4 à $8 \%$ de la demande annuelle pour la production primaire sur l'ensemble de l'année dans le golfe du Lion. (C) 2001 Ifremer/CNRS/IRD/Éditions scientifiques et médicales Elsevier SAS

\section{sediment-water flux / dissolved inorganic nitrogen / temporal variability / nitrogen cycling / NW Mediterranean}

\section{flux à l'interface eau-sédiment / azote inorganique dissous / variabilité temporelle / cycle de l'azote / Méditerranée nord occidentale}

\section{INTRODUCTION}

Available nitrogen plays a major role in controlling the growth of algae in the oceans, and therefore short or long-term changes in the global budget of dissolved inorganic nitrogen (DIN) may have important consequences (Codispoti, 1995). Despite intensive studies of nitrogen cycling, the complex transformation pathways of nitrogen compounds and the scales of both temporal and spatial variability are still weakly understood (Ganesham et al., 1995).

In nitrogen cycling, the benthic compartment has been shown to play a major role through mineralisation processes of particulate or dissolved organic nitrogen including ammonification, nitrification, denitrification (Blackburn and Sorensen, 1988). Such processes result in exchanges of DIN at the sediment-water interface and accumulation of DIN in the interstitial water.

In shallow waters, DIN exchanges at the sediment-water interface may provide a large part of the nitrogen requirements for phytoplankton, up to $30-80 \%$ in temperate estuaries (Blackburn and Henriksen, 1983; Kemp and Boynton, 1992). In those coastal systems, changing overlying water characteristics, hydrodynamic forcing on surficial sediments and organic matter inputs are generally considered as the main environmental factors influencing temporal variability of dissolved exchanges at the sediment-water interface (Jensen et al., 1990). This strong benthic-pelagic coupling also initiates a short- term temporal variability of mineralisation pathways in surficial sediments, thereby affecting DIN exchanges (Caffrey, 1995).

At greater depth, bottom water characteristics are less variable and hydrodynamical forcings are generally lower. The inputs of detritus via the vertical sedimentation of organic matter from the productive surficial waters, or lateral inputs from the continental margins constitute the major source of temporal variability (Soetaert et al., 1996; Gehlen et al., 1997). But, if the changes generally vary over a lower range than in shallow waters, they may not be neglected, all the more as the areas submitted to those variations are much wider.

Temporal variability in DIN exchanges at the sedimentwater interface might have important consequences in the NW Mediterranean Sea, an area which is generally considered as oligotrophic, and where the spring phytoplankton bloom is limited by nitrogen availability (Conan et al., 1998). This oligotrophic character is locally counterbalanced by the continental input from the Rhône River, as shown by the coastal zone colour scanner images, that reveal a permanent higher productivity in the Gulf of Lions than in the adjacent area (Morel and André, 1991). Nevertheless, TusseauVuillemin et al. (1998) pointed out that benthic exchanges of DIN need to be considered in pelagic models of this area. Numerous studies were carried out in the 
water column, but very little data about dissolved exchanges at the sediment-water interface are available.

In this context, the present study focuses on the temporal variability of benthic fluxes and interstitial gradients of DIN. Specifically, we performed a monthly survey at two stations located on the continental shelf and the upper slope. The sources of organic matter (i.e. vertical sinking, inputs from the Rhône River) were measured in parallel to the benthic studies.

\section{MATERIAL AND METHODS}

\subsection{Study site and sampling device}

The NW Mediterranean Sea is covered by a wide continental shelf (up to $70 \mathrm{~km}$ width, total area: $16000 \mathrm{~km}^{2}$ ). This shelf, called the Gulf of Lions, is influenced by inputs from the Rhône River, which is the largest source of freshwater in the Mediterranean Sea (except the Black Sea). This river has a mean annual river discharge around $1700 \mathrm{~m}^{3} \mathrm{~s}^{-1}$. A large part of the dissolved inputs to the Gulf of Lions originate from the Rhône River (Coste and Raimbault, 1993, 1995).

Two stations on the continental shelf (station R, depth: $97 \mathrm{~m}$ ) and near the upper continental slope (station Sofi, depth: $162 \mathrm{~m}$ ) were selected in the eastern part of the Gulf of Lions for a monthly survey, which was conducted from September 1997 to January 1999 (figure 1, table I). Considering the main flow direction of the North Mediterranean Current (Millot, 1987, 1990), the plume of the Rhône River is deviated westwards, and the influence of these inputs should be large at station $\mathrm{R}$, and rather low at Sofi.

Surficial sediments were sampled with a Mark VI sediment multicorer (Bowers and Connelly, Scotland) specifically designed to obtain four large-diameter Perspex cores (i.d.: $15 \mathrm{~cm}$, length: $50 \mathrm{~cm}$ ) with an undisturbed sediment-water interface (Barnett et al., 1984). The cores were selected by visual observation of a clear overlying water and multiple delicate biogenic microstructures at the sediment-water interface. Cores were maintained in the dark, at in situ temperature and were carefully brought to the laboratory where incubations were performed.

Bottom water temperature and salinity were recorded in situ by means of a Seabird (9117) CTD probe. Around

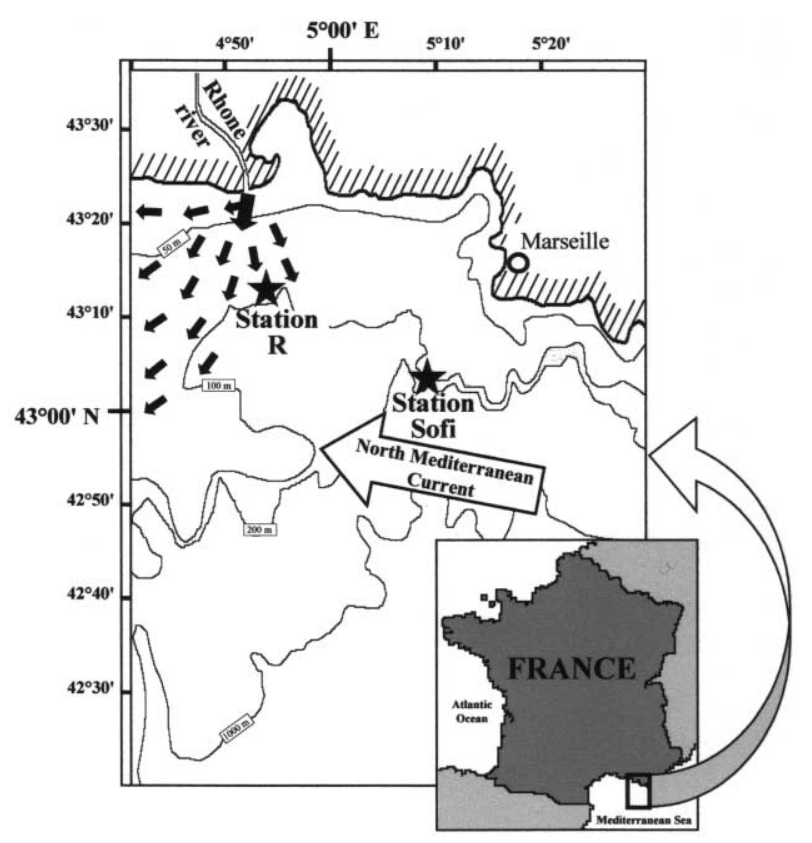

Figure 1. Bathymetric map showing the location of the two stations (Sofi and R) and the main hydrological features: North Mediterranean Current (open arrow), Rhône River plume (black arrows).

$20 \mathrm{~L}$ of bottom water were sampled with a Rosette sampler about $5 \mathrm{~m}$ above the sea floor and immediately placed in the dark and the same temperature as the cores.

\subsection{Incubation procedure}

Depending on the sampling efficiency, for each station three to four cores were incubated in the dark, at in situ temperature, in a thermoregulated cabinet. Cores were carefully sealed to exclude air bubbles and gently stirred with a floating magnet fixed to the upper cap (Cowan et al., 1996). Each core was linked by tubing to an inflatable reserve tank, which was filled with bottom water, again excluding air bubbles (figure 2). Sampling was performed with a plastic syringe in all the cores and in the reserve tank, and the overlying water removed in each core tube was replaced with bottom water from the reserve tank. Incubations lasted from 36 to $48 \mathrm{~h}$ during which eight to ten samplings were performed. Bottom water concentrations were calculated as the mean of nutrient concentrations in the reserve tank when no significant change was observed during the incubation. In few cases, a significant change was recorded, and the intercept at the origin of the 
Table I. Location, depth and sedimentary characteristics of the sampling sites.

\begin{tabular}{lll}
\hline & Station Sofi & Station R \\
\hline Location & $43^{\circ} 04^{\prime} 0 \mathrm{~N}-05^{\circ} 07^{\prime} 6 \mathrm{E}$ upper slope & $43^{\circ} 14^{\prime} 5 \mathrm{~N}^{\prime} 04^{\circ} 53^{\prime} 1 \mathrm{E}$ continental shelf \\
Depth $(\mathrm{m})$ & 162 & 97 \\
Bottom water temperature $\left({ }^{\circ} \mathrm{C}\right)$ & $13.6 \pm 0.2$ & $14.2 \pm 1.4$ \\
Bottom water salinity & $38.17 \pm 0.06$ & $38.08 \pm 0.07$ \\
Mean porosity $(0-10 \mathrm{~cm})$ & $0.47 \pm 0.05$ & $0.68 \pm 0.06$ \\
$\%$ sand & 34.3 & 1.2 \\
$\%$ silt & 46.1 & 61.7 \\
$\%$ clay & 19.5 & 37.2 \\
\hline
\end{tabular}

Bottom water temperature, salinity and porosity are averaged $( \pm \mathrm{SD})$ for all the survey. Sediment characteristics were analysed in June.

linear regression was then regarded as bottom water concentration.

\subsection{Analytical procedure and fluxes calculation}

Immediately after retrieval, each water sample was filtered through a GF/F Whatman glass fibre filter and vials were rinsed once before sample collection. Ammonium concentration was analysed immediately (Solorzano,

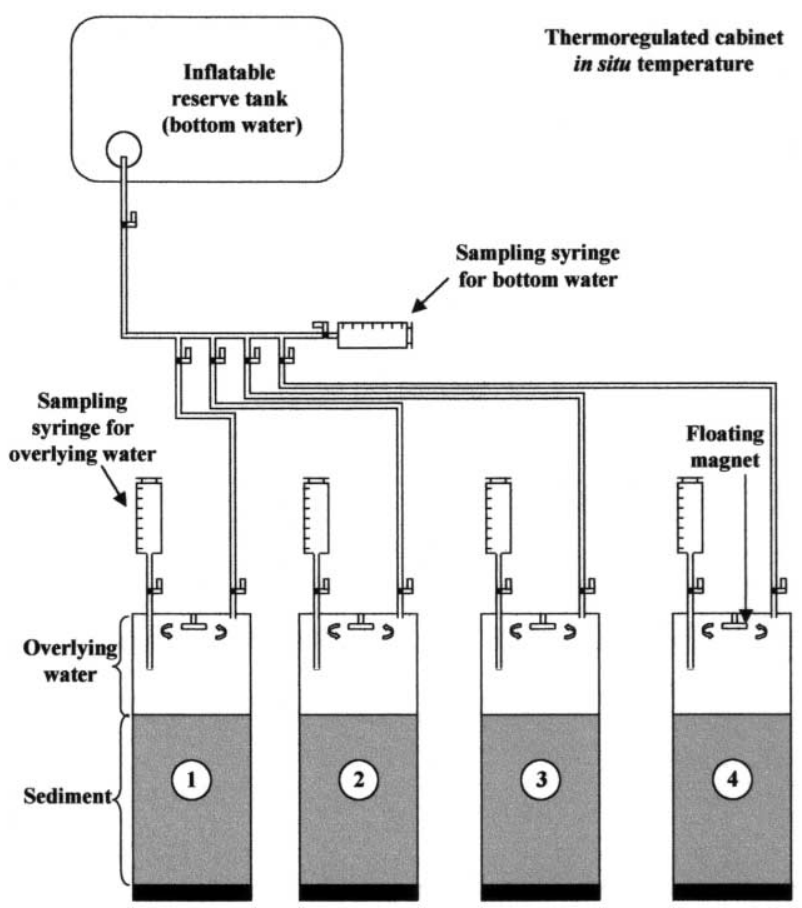

Figure 2. The experimental device for benthic flux measurements using whole core incubation technique.
1969). Nitrate and nitrite samples were frozen until later analysis with a Technicon autoanalyser according to the technique of Tréguer and Le Corre (1975). In this paper, dissolved inorganic nitrogen (DIN) will be considered as the sum of $\mathrm{NH}_{4}^{+}, \mathrm{NO}_{3}^{-}$, and $\mathrm{NO}_{2}^{-}$nitrogen.

Fluxes were calculated by regressing the change of nutrient concentrations in the overlying water against time. All the data were integrated in this calculation since no change of the slope was observed during the incubation. This calculation was corrected for the dilution with bottom water at each sampling point, and for changes in nutrient concentrations in the reserve tank, when significant. Only significant fluxes $(P<0.05)$ were used, otherwise they were considered as a zero flux. Fluxes directed from the sediment to the water column were considered as positive.

\subsection{Interstitial water and sediment analyses}

At the end of the incubation, sediments from two to four core tubes (i.d.: $15 \mathrm{~cm}$ ) were analysed. Each incubation core was subsampled with seven small diameter cores (i.d.: $2.7 \mathrm{~cm}$ ). For interstitial water analysis, six of these subcores were cut into $1 \mathrm{~cm}$ thick slices down to $10 \mathrm{~cm}$ depth and slices from the same depth were pooled in two similar series in centrifuge tubes. After centrifugation $(4500 \times g, 20 \mathrm{~min})$ supernatant was carefully removed and further analysed following the same analytical procedure as for overlying water. The remaining subcore was used for water content determination, which was achieved by drying at $60^{\circ} \mathrm{C}$ in an oven until constant weight. Porosity was subsequently calculated assuming a bulk density of $2.65 \mathrm{~g} \mathrm{~cm}^{-3}$. Granulometric analyses 
were performed on both stations in June 1998 by means of a laser granulometer (Laser Malvern Mastersizer).

\subsection{Diffusive flux calculation}

Diffusive Fluxes $\left(F_{\text {Diff }}\right)$ were estimated according to Fick's first law by calculating a linear gradient between surficial pore water concentration and bottom water concentration of solute $(C)$ in the sediment:

$$
F_{\text {Diff }}=-\phi D_{\mathrm{S}}^{T}(\delta C / \delta z)
$$

with $D_{\mathrm{S}}{ }^{T}$, the effective diffusion coefficient of the solute $C$ in the sediment, $\phi$, the porosity, and $z$ the depth in the sediment.

The effective diffusion coefficient of a solute in the sediment must take into account the convoluted path molecules must follow around sediment particles (i.e. tortuosity: $\theta$ ). Following Berner (1980), we used Archie's law $\left(\theta^{2}=\phi^{(1-m)}\right)$, with the empirical coefficient $m=3$ (Ullman and Aller, 1982). The effective diffusion coefficient $\left(D_{\mathrm{S}}{ }^{T}\right)$ of a solute in the sediment was then calculated as follows:

$$
D_{\mathrm{S}}^{T}=D^{T} \theta^{-2}=D^{T} \phi^{2}
$$

where $D^{T}\left(\mathrm{~cm}^{2} \mathrm{~s}^{-1}\right)$ is the infinite dilution diffusion coefficient at the ambient temperature $T\left({ }^{\circ} \mathrm{C}\right)$. This value was calculated from the zero-degree coefficient $D^{0}$ $\left(\mathrm{cm}^{2} \mathrm{~s}^{-1}\right)$ according to Boudreau (1997):

$$
\mathrm{D}^{T}=D^{0}+a T
$$

where $a\left(\mathrm{~cm}^{2} \mathrm{~s}^{-10} \mathrm{C}^{-1}\right)$ is an ion specific coefficient.

\section{RESULTS}

\subsection{Bottom water}

Mean annual bottom water temperature and salinity were around $13.6^{\circ} \mathrm{C}$ and 38.2 at station Sofi with small variation, and bottom water temperature at station $\mathrm{R}$ was generally in the range $12.8-15.3^{\circ} \mathrm{C}$ (except November 1997: $17.9^{\circ} \mathrm{C}$ ), with salinity always around 38.1 (table I).

Nutrient concentrations in the bottom water were generally quite low, ranging from undetectable values up to
$0.5,6$ and $1.4 \mu \mathrm{M}$ respectively for ammonium, nitrate and nitrite (figure 3). At station Sofi, nitrate always represented 77 to $99 \%$ of the total amount of DIN in the bottom water and was in the range $40-95 \%$ for station $\mathrm{R}$ (except November 1997: no detectable nitrate concentration). Nitrate concentrations were significantly lower at station R than at station Sofi, while higher nitrite concentrations were recorded (pair-wise $t$-test, $P<0.05$ ). No significant difference was observed for ammonium. During the survey, changes in the characteristics of the bottom water were generally measured simultaneously at both stations. An increase of nitrate concentration was observed in January and a second increase was measured from May-June until August-September, both followed by a decrease in concentrations. A similar trend was observed for nitrite, but the second peak was only observed in June and higher concentrations were measured during the first peak. Bottom water was almost depleted in nitrate and nitrite in autumn 1997 and 1998. The temporal variations in ammonium concentrations showed no significant trend but generally, lowest concentrations were recorded from May until August.

\subsection{Nutrient fluxes}

At station Sofi, nitrate fluxes were always directed from the sediment to the water column, in the range $2.8-10.1 \mu \mathrm{mol} \mathrm{m}^{-2} \mathrm{~h}^{-1}$ (figure $4 a$ ). Low nitrate fluxes were measured in winter 1998, increasing during May and June, and the highest ones were observed in August 1998. Afterwards, a sharp decrease was observed down to values in the range $2.8-5 \mu \mathrm{mol} \mathrm{m}^{-2} \mathrm{~h}^{-1}$ in September-October 1998. Ammonium fluxes were very low $\left(<1.2 \mu \mathrm{mol} \mathrm{m}^{-2} \mathrm{~h}^{-1}\right.$, except in November 1997: $2.3 \mu \mathrm{mol} \mathrm{m}{ }^{-2} \mathrm{~h}^{-1}$ ) and generally directed out of the sediment. A peak of ammonium release from the sediment was observed in August (more than $10 \mu \mathrm{mol} \mathrm{m}^{-2} \mathrm{~h}^{-1}$ ), following a slight increase in June. But the data from the four August cores showed great differences as represented by the large standard deviation. Nitrite fluxes were always lower than $0.4 \mu \mathrm{mol} \mathrm{m}{ }^{-2} \mathrm{~h}^{-1}$ and the highest fluxes were directed into the sediment. Positive nitrite fluxes were always in the range $0.04-0.2 \mu \mathrm{mol} \mathrm{m}^{-2} \mathrm{~h}^{-1}$. As a consequence, DIN exchanges were always positive with maximal exchanges at the sediment-water interface in summer. Nitrate fluxes always represented more than $75 \%$ the DIN fluxes, except in August when ammonium contributed almost half the DIN fluxes. 

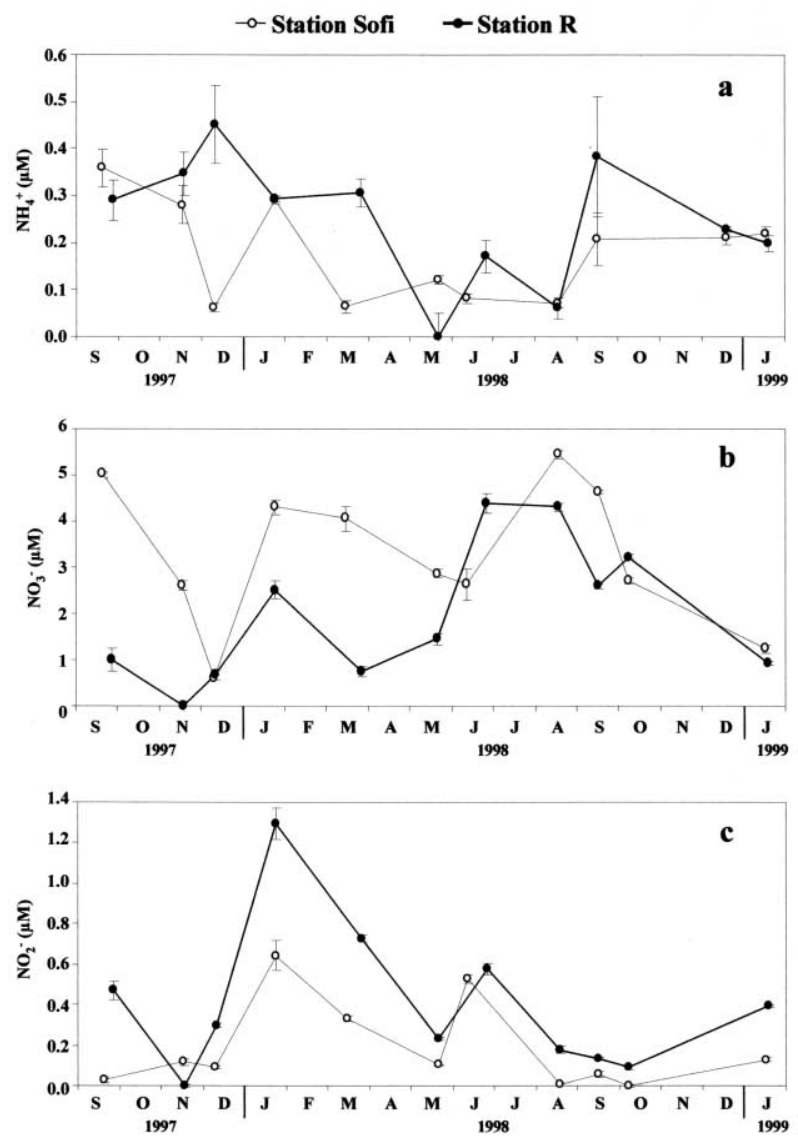

Figure 3. Mean values $( \pm$ SD) of ammonium (a), nitrate (b) and nitrite (c) concentrations measured in the bottom water at station Sofi (open circles) and station $\mathrm{R}$ (solid circles) during the survey.

At station R, exchanges of nitrate, ammonium and nitrite were generally more intensive than at station Sofi (figure $4 b$ ). Nitrate fluxes were always positive, in the range $4.5-13.5 \mu \mathrm{mol} \mathrm{m}{ }^{-2} \mathrm{~h}^{-1}$. Large variations were observed in autumn-winter 1997-98, with maximal values in November 1997 and January 1998 and the lowest value of the whole survey in December 1997. Afterwards, and until the end of the survey, nitrate fluxes showed a trend similar to the one observed at station Sofi, with an increase in June and August 1998. Ammonium fluxes were also directed from the sediment to the overlying water, with maximal values in winter 1998 (7-9 $\mu \mathrm{mol} \mathrm{m}{ }^{-2} \mathrm{~h}^{-1}$ ). Nitrite fluxes were generally negative (except in January 1998: $0.5 \mu \mathrm{mol} \mathrm{m}^{-2} \mathrm{~h}^{-1}$ ) and showed minimal values in December 1997 $\left(-0.9 \mu \mathrm{mol} \mathrm{m} \mathrm{m}^{-2} \mathrm{~h}^{-1}\right)$. DIN fluxes were always positive, as at station Sofi but with higher values. Time distributions
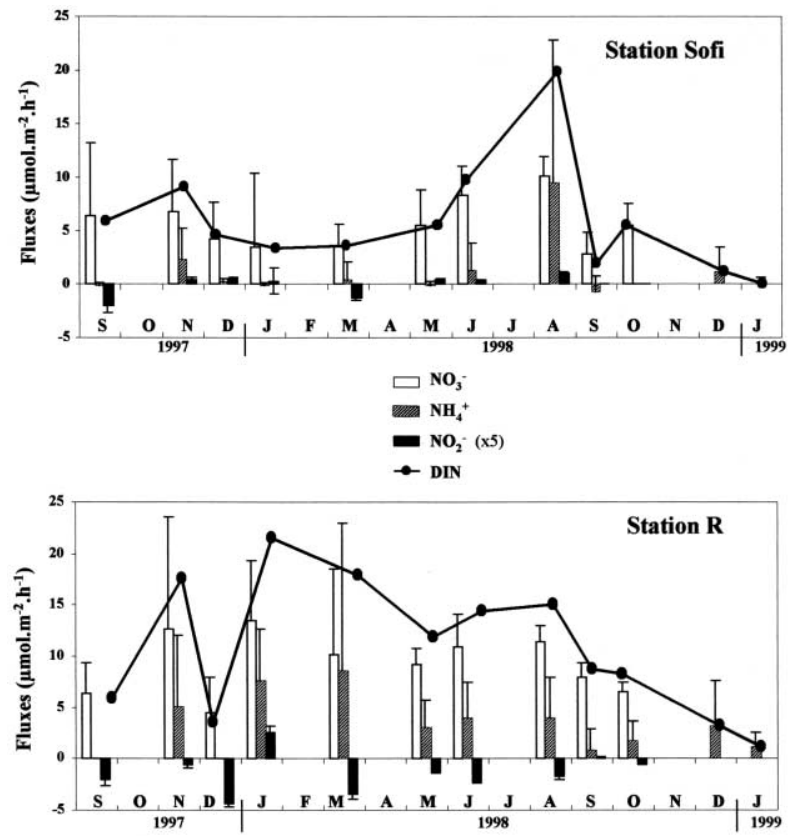

Figure 4. Nitrate $\left(\mathrm{NO}_{3}^{-}\right)$, ammonium $\left(\mathrm{NH}_{4}^{+}\right)$and nitrite $\left(\mathrm{NO}_{2}^{-}\right)$ fluxes across the sediment-water interface during the survey at station Sofi (a) and station R (b). Dissolved inorganic nitrogen fluxes (DIN), calculated as the sum of nitrate, ammonium and nitrite fluxes are also plotted. Positive fluxes are directed from the sediment to the watercolumn.

of DIN fluxes are similar to the ones observed for nitrate, which contributed $50-90 \%$ of total DIN fluxes. Large variations of DIN fluxes were observed from November 1997 to January 1998, and in December a low nitrate release is partly counterbalanced by nitrite flux into the sediment. From the maximal DIN release observed in January $1998\left(21.6 \mu \mathrm{mol} \mathrm{m}{ }^{-2} \mathrm{~h}^{-1}\right)$ until the end of the survey, a general decrease of DIN release is evidenced, with a slight increase in summer (up to $\left.14-15 \mu \mathrm{mol} \mathrm{m}{ }^{-2} \mathrm{~h}^{-1}\right)$.

\subsection{Sediment and interstitial water}

The granulometric characteristics of both stations are reported in table I. At station $\mathrm{R}$, the muddy sediment is almost entirely comprised of silt and clay (98.8\%). Conversely, at station Sofi, over $34 \%$ of the sediment is sand. For both stations, porosity profiles were averaged as no significant change was recorded during the survey. At station Sofi, mean porosity in the first centimetre was around 0.58 , and then decreased exponentially $(n=10$, 

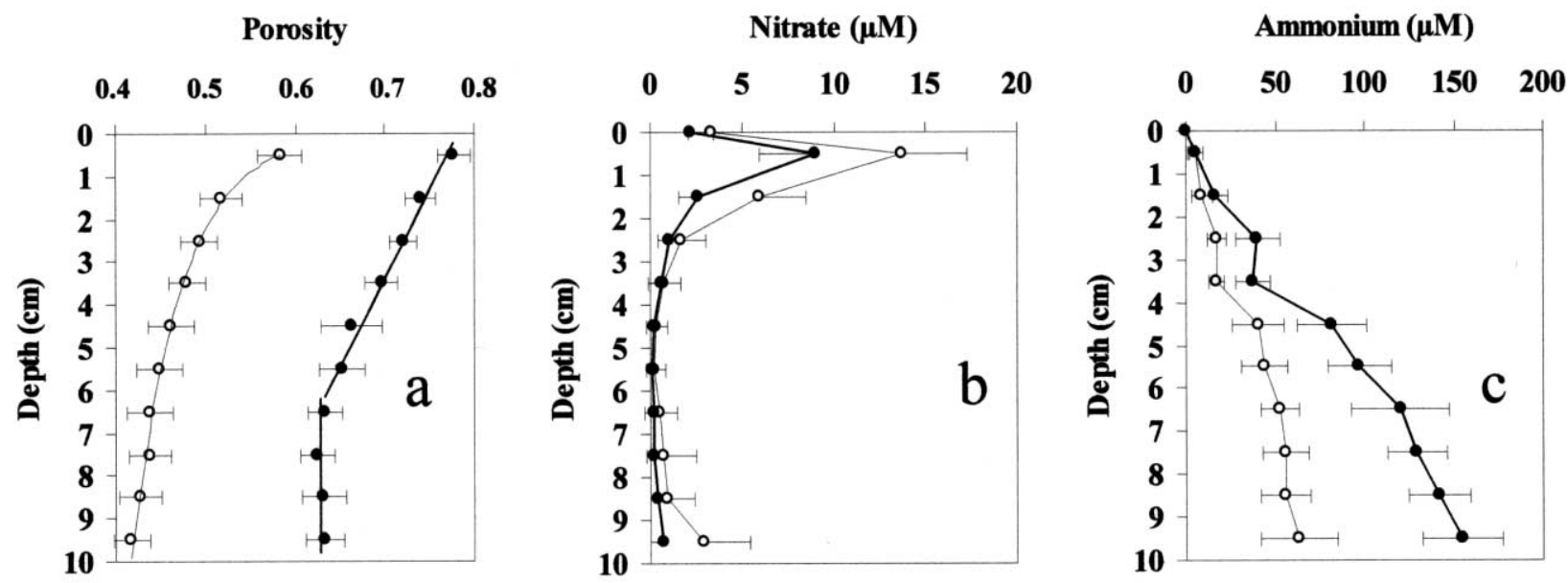

\section{- - Station Sofi $\quad \rightarrow$ Station R}

Figure 5. Averaged $( \pm \mathrm{SD})$ annual profiles at stations Sofi (open circles) and R (solid circles) of porosity (a), pore-water concentrations of nitrate (b) and ammonium (c). For porosity profiles, the curve corresponds to the exponential decrease of porosity ( $p$ ) with depth $(z)$ : $p(z)=0.384+0.224 \mathrm{e}^{-0.361 z}\left(n=10, r^{2}=0.997\right)$ for station Sofi. For station $\mathrm{R}$ the lines correspond respectively to the best linear adjustment obtained on the $0-6 \mathrm{~cm}$ slices : $p(z)=-0.024 z+0.78\left(n=6, r^{2}=0.984\right)$ and to the mean value $p(z)=0.63$ at depth.

$r^{2}=0.997$ ) with depth down to a value of 0.4 (figure $5 a$ ). For station R, porosity in the upper layer was 0.78 , but the decrease with depth was not clearly fitted with an exponential decrease. The decrease was almost linear down to $5-6 \mathrm{~cm}\left(n=6, r^{2}=0.986\right)$. Below this, the porosity remained largely unchanged (approx. 0.63 ).

The interstitial profiles of nitrate did not show significant variations over the sampling period and therefore, the data presented here are mean values (figure $5 b$ ). The value at depth $0 \mathrm{~cm}$ is also the annual average of bottom water concentrations. The profiles obtained for both stations were quite similar, with a maximal nitrate concentration in the first centimetre, around $6.6 \mu \mathrm{M}$ at station $\mathrm{R}$ and $8.6 \mu \mathrm{M}$ at station Sofi. Then, an exponential decrease was observed down to $4 \mathrm{~cm}$. The values obtained deeper are very low and, considering the standard deviation, are never significantly different from zero.

The profiles of ammonium at station Sofi were similar during most of the year, except for June and August sampling dates. The profiles observed at both stations show similar trends (figure 5c), but the concentrations were always twice as high at station $\mathrm{R}$, with the exception of the first centimetre. A slight increase was observed in the 3 surficial centimetres, and the average value observed in the 3-4 cm slice was always lower than the one observed in the $2-3 \mathrm{~cm}$ slice. Significant increase in ammonium concentrations was observed between 3.5 and $4.5 \mathrm{~cm}$. At greater depth, a linear increase was evidenced, up to maximal concentrations of 64 and $155 \mu \mathrm{M}$ respectively at station Sofi and R.

\section{DISCUSSION}

\subsection{Bottom water nutrients and impact on exchange processes}

The mean annual nutrient concentrations in bottom water are in accordance with general vertical profiles observed in the upper water column from the coastal zone to the open sea (Cruzado, 1995). Temporal variability has been evidenced in the upper layers of the water column (Conan, 1996) where it is basically linked to stratification-destratification processes and to wind effects. In this study, we also evidenced seasonal variations of nutrient concentrations in bottom water.

An increase in concentration was observed at both stations for nitrate and nitrite in January. This period generally corresponds to intensive vertical mixing and massive discharge from the Rhône River (high concentrations of nitrate and nitrite), which might explain this increase. This effect might also be due to a winter 
upwelling of deep water along the continental slope, and on the continental shelf (Millot, 1990; Denis, 1999). The second increase observed from June to September for nitrate and in June for nitrite might be linked to water column stratification occurring in summer (warmer surrounding water layer: $18-25^{\circ} \mathrm{C}$ ). In this case, vertical exchanges in the water column are reduced and nutrient release from sediments might contribute to the nutrient accumulation in bottom water.

Such a variability of bottom water concentrations might affect sediment-water exchanges of dissolved species, as previously described in shallow coastal embayments or estuaries (Koop et al., 1990; Cowan et al., 1996). But, in our study, no significant correlation is observed between the intensity of fluxes and bottom water concentration. This is not surprising as the values of bottom water concentrations and sediment-water fluxes vary in a very low range in comparison to shallower systems where fluxes and bottom water concentrations may change drastically over short periods (Nowicki and Nixon, 1985; Grenz et al., 2000).

\subsection{Nitrogen mineralization processes}

The previous statement that station $\mathrm{R}$ is directly subjected to the inputs from the Rhône River was confirmed by sediment grain size: more than $98 \%$ of the sediment comprised pelites (clays and silts). Station Sofi, situated on the upper slope, has totally different sediment characteristics, with less than $20 \%$ clay. Despite these differences, interstitial water profiles are quite similar. At both stations, nitrate accumulates in the upper centimetre (concentrations twice as high as in the overlying water), because of nitrification processes in the oxic surficial layers of the sediment (Henriksen and Kemp, 1988; Denis, 1999). Denitrification processes are inhibited by oxygen in the upper layers of the sediment and allow nitrate accumulation (Devol and Christensen, 1993). Deeper down to $4 \mathrm{~cm}$ depth, the nitrate concentration decreases because of anaerobic nitrate consumption (Balzer, 1984). Nitrate assimilation (Blackburn et al., 1996) and dissimilatory nitrate reduction to ammonium (Enoksson and Samuelsson, 1987) may also contribute to lower nitrate concentrations. Deeper in the cores, nitrate concentrations are never significantly different from zero. For both stations, a general increase with depth in ammonium concentration is observed, linked to ammonification processes. A linear gradient is observed at depth greater than $4-5 \mathrm{~cm}$ as the consequence of ammonium accumulation due to regeneration by anaerobic metabolism (Christensen and Rowe, 1984).

These considerations are consistent with the fact that higher organic matter input, or its rapid burial into the sediments, result in a lower percentage of total mineralisation occurring in the surficial oxidised layers of the sediment (Middelburg et al., 1993). Organic matter is buried at depths where both oxygen and nitrate (consequently nitrification and denitrification) are unavailable, and therefore undergoes mineralisation via other anaerobic pathways (Santschi et al., 1990; Van Cappellen and Wang, 1996). At station R, subjected to higher organic matter inputs, a larger amount of organic matter is available for degradation, and intense mineralisation processes explain higher DIN fluxes at the sediment-water interface (Cowan et al., 1996). Moreover, the anaerobic pathways may represent a larger fraction of total mineralisation than at station Sofi, because vertical transport processes (down to anaerobic layers) are enhanced. This leads to higher ammonium accumulation, and consequently to higher ammonium release from sediments. Nitrification processes may be of the same order of magnitude for both stations, but prevail in terms of exchanges at station Sofi because anaerobic processes resulting in ammonium exchanges are low. Moreover, high nitrification rate, coupled with lower denitrification rates might explain the high release of nitrate and lower ammonium fluxes at the sediment-water interface (Conley and Johnstone, 1995; Bertuzzi et al., 1996).

\subsection{Total versus diffusive fluxes}

Diffusive flux calculations are compared with total fluxes at the sediment-water interface as measured by core incubation (table II). In the calculation of diffusive fluxes, irrigation is neglected and the diffusion coefficient $D_{\mathrm{S}}{ }^{T}$ only includes molecular diffusion around sediment particles. Estimates of bioturbation coefficients from the literature are still inaccurate, being time and space dependent, and therefore were not included in this calculation. The calculated diffusive fluxes must therefore be considered as minimal diffusive fluxes (only molecular diffusion; Callender and Hammond, 1982; Emerson et al., 1984). Nevertheless, as the biologically mediated vertical transport of solutes must be similar for both ammonium and nitrate, the relative comparisons made hereafter are justified. 
Table II. Diffusive fluxes calculated from the gradients observed in the sediment.

\begin{tabular}{|c|c|c|c|c|}
\hline & \multicolumn{2}{|c|}{ Station Sofi } & \multicolumn{2}{|c|}{ Station R } \\
\hline & $\mathrm{NH}_{4}^{+}$ & $\mathrm{NO}_{3}^{-}$ & $\mathrm{NH}_{4}^{+}$ & $\mathrm{NO}_{3}^{-}$ \\
\hline Total fluxes (annual average) & 1.15 & 5.67 & 3.27 & 9.30 \\
\hline \multicolumn{5}{|l|}{ Diffusive fluxes } \\
\hline BW $(0-1)^{1}$ & 1.23 & 2.35 & 2.58 & 3.46 \\
\hline$(0-1)-(1-2)^{2}$ & 0.33 & -0.69 & 2.76 & -1.51 \\
\hline Gradient $>4 \mathrm{~cm}^{3}$ & 0.26 & 0.02 & 2.52 & 0.02 \\
\hline
\end{tabular}

Values are in $\mu \mathrm{mol} \mathrm{m} \mathrm{m}^{-2} \mathrm{~h}^{-1}$. Molecular diffusion coefficients were respectively $15.3 \times 10^{-5}$ and $14.9 \times 10^{-5} \mathrm{~cm}^{2} \mathrm{~s}^{-1}$ for ammonium and nitrate. Bottom water, interstitial concentrations, and porosity are averaged over the year. Calculations were performed assuming a linear gradient between the 1 st slice $(0-1 \mathrm{~cm})$ and bottom water ${ }^{1}$, a linear gradient between the $1 \mathrm{st}(0-1 \mathrm{~cm})$ and 2 nd $(1-2 \mathrm{~cm})$ slices ${ }^{2}$, and a linear gradient from 4 to $10 \mathrm{~cm}^{3}$.

At station Sofi, diffusive fluxes calculated in between the first and second centimetres, and deeper in the core are similar, quite low, but the diffusive flux increases drastically at the sediment-water interface, and an overestimation of ammonium fluxes out of the sediment is observed. In contrast, diffusive fluxes calculated for station $\mathrm{R}$ are similar for the different depths and thus in equilibrium with the concentrations observed in the bottom water. This is not the case for station Sofi and this discrepancy between the two stations may be related to a high nitrification rate in the first centimetre of the sediment at station Sofi (may be related to macrofaunal activity; Mayer et al., 1995), constituting a sink of ammonium in this layer, and thus a major source of nitrate (Blackburn and Henriksen, 1983). High inputs of ammonium through organic matter mineralisation in the first centimetre of the sediment (probably in the first millimetres), as well as the poor vertical resolution of the interstitial gradients, may explain the absence of ammonium depletion in the ammonium profiles. This is also consistent with the fact that nitrate flux as calculated with the sediment gradient is much lower than the total flux measured via incubation. Moreover, high nitrate fluxes out of the sediment may account for a large loss of nitrate from the first centimetre, hence preventing nitrate accumulation. Nitrate profiles show a downward diffusive flux in between the first-second centimetres, but nitrate does not accumulate deeper in the core and undergoes denitrification processes.

It must also be noted that ammonium profiles obtained in June and August for station Sofi were not included in the calculation of the sedimentary gradient. These are typical of non steady-state conditions (Vidal and Morgui, 1995), with maximal concentrations at depths of 3.5 and $2.5 \mathrm{~cm}$ and were previously observed during sediment enrich- ment experiments (Conley and Johnstone, 1995). Moreover including these profiles in the calculation of diffusive flux would not have changed the general annual trend.

\subsection{Factors influencing temporal variability of DIN fluxes}

The temporal variability in DIN release might be due to a rapid modification of mineralization pathways or to a massive input of organic matter settling on surficial sediments and rapidly undergoing mineralization. As the increase is observed in a quite similar proportion for both ammonium and nitrate fluxes, the main temporal variability seems not to be related to a modification of nitrogen mineralization pathways, which would have resulted in changes in the balance between the fluxes of dissolved species (mainly nitrate versus ammonium) at the sediment-water interface.

If the hypothesis of organic matter input is considered, two major sources must be taken into account: 1 ) inputs from the Rhône River during high river discharge or floods, and/or 2) primary production in the euphotic zone and its sedimentation. To study the origin of organic matter, we analysed both the Rhône River flow measurements in Beaucaire (65 km upstream the river mouth) obtained from the 'Compagnie Nationale du Rhône' (figure $6 a$ ) and continuous recordings of a PPS5 sediment trap (one square metre mouth) located $20 \mathrm{~m}$ above the bottom at station Sofi (figure $6 b$, P. Raimbault, unpublished data).

Despite numerous dams along the river, the discharge close to the mouth shows a high temporal variability (600 

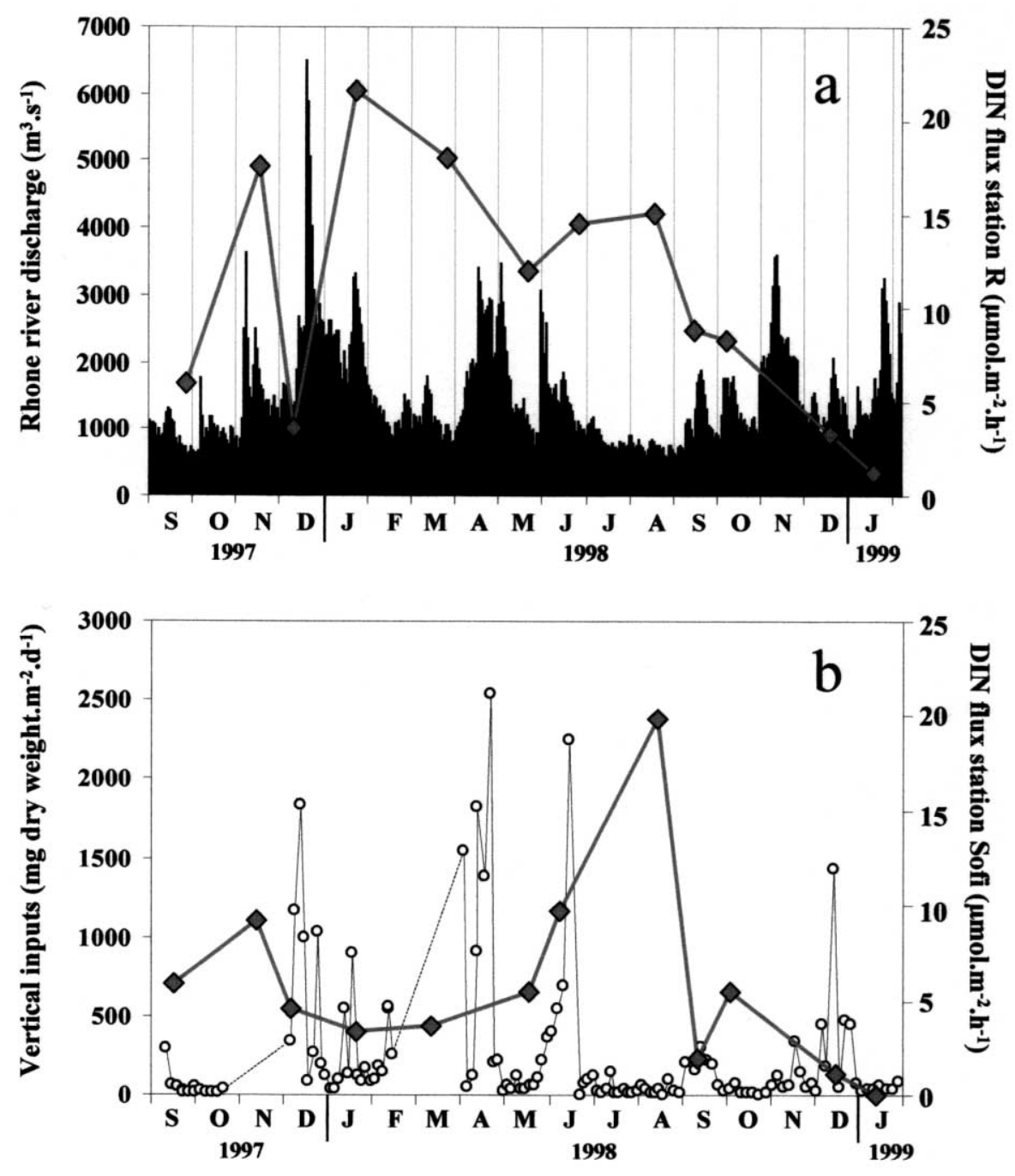

Figure 6. Time series of external DIN sources compared to sediment DIN fluxes. a. daily averaged Rhône River discharge recorded during the survey period (in black) and DIN flux at station R (in grey). b. 3-4 days averaged inputs in the sediment trap given as dry weight inputs $(20 \mathrm{~m}$ above the bottom at station Sofi; in black, dashed line: no data) and DIN flux at station Sofi (in grey).

to $6500 \mathrm{~m}^{3} \mathrm{~s}^{-1}$ during the survey), due to a large variety of sources: rain, melting of snow or ice (glaciers). A low river discharge was observed in September-October 1997 and in summer 1998. Maximal discharges were recorded in December 1997-January 1998 and resulted from Mediterranean storms. Moreover, high discharges were also observed in April-June 1998 and may be linked to melting of snow. From November 1998 to January 1999, high discharges were also recorded, but were significantly lower than in 1997-98, which illustrate the interannual variability of the river discharge.

Sediment trap data are averaged over a period of 3-4 days, except between November 1997 and February-March 1998 when no data are available. We observed an increase of vertical inputs in December 1997, April and June 1998, which occurred simultaneously with the maximal discharge of the Rhône River. In spring 1998, the increase of vertical inputs might also be related to the settlement of fresh organic matter originated from the spring phytoplankton bloom.

As mentioned above, both of these inputs may contribute to increase benthic activity and consequently have an impact on temporal variability in nitrogen mineralization. Therefore, those data are compared to DIN fluxes at the sediment-water interface at stations $\mathrm{R}$ (figure $6 a$ ) and Sofi (figure $6 b$ ). No significant correlation was observed between the external inputs and DIN release from sediments. Such a statement is not surprising as the 
sampling time step is monthly for sediment-water fluxes, whereas vertical inputs are averaged over 3-4 days. The time lag between organic matter input and mineralization processes in surficial sediments also needs to be considered. Nevertheless, increases of DIN release from sediments are generally obtained after a period of higher inputs. This trend is evidenced for the DIN peak observed in January 1998 at station R, which is consecutive to the maximal river discharge in December 1997, but also for the June-August 1998 period, with higher DIN fluxes following higher inputs both in the sediment trap and from the Rhône River.

\subsection{Annual budgets}

Mean annual budgets of DIN in the sediments were calculated for both stations with a linear interpolation between samplings. As shown in earlier studies in the Mediterranean Sea (Blackburn, 1991), sediments act as a major source of DIN, with a mean annual release of 6.7 and $11.4 \mu \mathrm{mol} \mathrm{m}{ }^{-2} \mathrm{~h}^{-1}$ for Sofi and $\mathrm{R}$, mainly attributable to nitrate release. Moreover, we may consider that these two stations, located on the continental shelf in front of the Rhône River, and on the upper slope out of the direct influence of the Rhône River, might give an estimate of DIN fluxes in the whole Gulf of Lions' continental shelf. Considering a shelf area (depth $<200 \mathrm{~m}$ ) of $16000 \mathrm{~km}^{2}$, the mean annual input of DIN originated from the sediment is in the range $13000-22000 \mathrm{t} \mathrm{N}_{\text {year }}{ }^{-1}$ for the Gulf of Lions. This value corresponds to $4-8 \%$ of the $\mathrm{N}$-demand for primary production (based on data from Morel and André, 1991). Comparatively, with an average DIN concentration of $100 \mu \mathrm{M}$ (Coste and Raimbault, 1993) and a mean annual river discharge of $1450 \mathrm{~m}^{3} \mathrm{~s}^{-1}$ (year 1998, data from the 'Compagnie Nationale $d u$ Rhône'), the Rhône River inputs are 65000 t $\mathrm{N}$ year ${ }^{-1}$. Thus, inputs of DIN from the sediment-water interface are equivalent to $20-34 \%$ of the Rhône River inputs in the Gulf of Lions. We also need to consider the temporal variability of both DIN fluxes at the sediment-water interface and Rhône River discharge. This is illustrated in figure 7, in which DIN flux out of the sediment is expressed as a percentage of the Rhône River inputs. For these calculations, we interpolated linearly between monthly sediment-water flux measurements for both stations, and considered the moving average over 30 days of the river discharge times the yearly average concentration of the Rhône River. The DIN inputs from sedi-

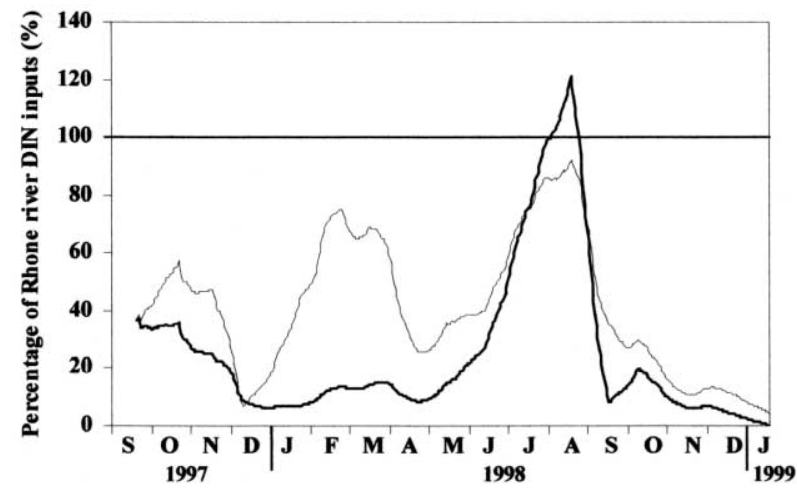

Figure 7. Inputs of DIN from sediments for the whole Gulf of Lions based on sediment-water fluxes from stations Sofi (thin) and R (bold), and expressed as a percentage of the Rhône River DIN inputs (moving averages of 30 days, see text).

ments may have a large influence, especially during late winter and summer when the river discharge is lower. These inputs may therefore contribute to spring primary production and, in a larger part to autumn production in the water column after mixing events. This calculation does not take into account the temporal variability in DIN concentrations in the Rhône River evidenced by Tusseau and Mouchel (1995), which would increase the seasonal effect. In this budget, the inputs from the North Mediterranean Current also need to be considered. These have been estimated by Conan (1996) who calculated an input of around $75000 \mathrm{t} \mathrm{NO}_{3}{ }^{-}$year $^{-1}$, equivalent to only three to five times the input from the sediments.

The budget presented in this paper constitutes a first estimate including sediment-water exchanges for the Gulf of Lions' continent shelf. To improve this budget, two points need to be investigated in the future: 1) the spatial study of benthic regeneration processes, and 2) the spatial influence of the two sources of organic matter evidenced in this study with respect to benthic organisms. These two points will be the aim of further investigations in the Gulf of Lions.

\section{CONCLUSION}

In this study, sediment-water DIN fluxes on the continental shelf in the Gulf of Lions have been estimated. Bottom water nutrient concentrations show temporal changes but these are not correlated with sediment-water exchanges and the variation range is probably too limited to affect fluxes significantly. Sedimentary characteristics 
confirm that station Sofi is away from the influence of the Rhône River whereas station $\mathrm{R}$ is directly affected by organic matter input from the river. In spite of different sediment grain size and porosity, interstitial profiles are similar for nitrate at both stations, but higher ammonium concentrations are observed at station $\mathrm{R}$. The calculation of diffusive fluxes suggests an intense nitrification pathway in the first centimetre at station Sofi, and this process might be coupled to lower denitrification rates. Consequently, nitrate release always constitutes the major part (52-88\% at station R, 73-98\% at station Sofi) of DIN fluxes, which are twice as high at station $\mathrm{R}$, averaging $11.4 \mu \mathrm{mol} \mathrm{m} \mathrm{m}^{-2} \mathrm{~h}^{-1}$ over the year, whereas the mean value observed at station Sofi is $6.7 \mu \mathrm{mol} \mathrm{m}{ }^{-2} \mathrm{~h}^{-1}$.

A high temporal variability of sediment-water exchanges in DIN was observed and a link to organic matter sedimentation was evidenced. The major increase observed at station Sofi was probably due to the settlement of a spring phytoplankton bloom as recorded by a near-bottom sediment trap. At station $\mathrm{R}$, the maximal release of DIN was observed after the maximal river discharge observed in December 1997-January 1998, and the effect of the spring bloom settlement was limited.

A DIN budget calculated for the continental shelf of the Gulf of Lions shows that fluxes from the sediment are equivalent to $20-34 \%$ of Rhône River inputs, with higher relative inputs in summer (minimal river discharge, higher DIN release). Sediment release contributes 4-8\% of the DIN requirements for primary production over the year, and should be included in future nitrogen budgets for the Gulf of Lions.

\section{Acknowledgements}

This survey was supported by the French 'Programme National d'Environnement Côtier' through the cruises Sofi (Station d'observation fixe) and Moogli (Modélisation et observation du golfe du Lion). The authors would like to thank the captains and crews of the research vessels N/O Tethys II, N/O Prof. Georges Petit, N/O L'Europe, N/O Suroit and N/O L'Atalante used during the survey. Thanks also to Martyn Harvey (Dunstaffnage Marine Laboratory, Oban, Scotland) for revising an earlier version of this paper. We are also very grateful to P. Raimbault for providing sediment trap data, D. Raphel for her help in Technicon analysis and G. Coustillier for CTD handling and data processing.

\section{REFERENCES}

Balzer, W., 1984. Organic matter degradation and biogenic element cycling in a nearshore sediment (Kiel Bight). Limnol. Oceanogr. 29, 1231-1246.

Barnett, P.R.O., Watson, J., Connelly, D., 1984. A multiple corer for taking virtually undisturbed samples from shelf, bathyal and abyssal sediments. Oceanol. Acta 7, 399-408.

Berner, R.A., 1980. Early diagenesis: a theoretical approach. Princeton University Press, Princeton.

Bertuzzi, A., Faganeli, J., Brambati, A., 1996. Annual variations of benthic nutrient fluxes in shallow coastal waters (Gulf of Trieste, Northern Adriatic Sea). P.S.Z.N.I. Mar. Ecol. 17, 261-278.

Blackburn, T.H., 1991. Mineralisation in Northwestern Mediterranean Sea sediments: Cybele cruise. In: Martin, J.M., Barth, H. (Eds.), Water pollution research report 28 - EROS 2000. Third project workshop, Den Burg/ Texel. CEC Directorate general for science, research and development, Brussels, pp. 469-479.

Blackburn, T.H., Hall, P.O.J., Hulth, S., Landen, A., 1996. Organic N loss by efflux and burial associated with low efflux of inorganic $\mathrm{N}$ and with nitrate assimilation in Arctic sediments. Mar. Ecol. Prog. Ser. 141, 283-293.

Blackburn, T.H., Henriksen, K., 1983. Nitrogen cycling in different types of sediments from Danish waters. Limnol. Oceanogr. 28, 477-493.

Blackburn, T.H., Sorensen, J., 1988. Nitrogen in coastal marine environments. Wiley and Sons, New York.

Boudreau, B.P., 1997. Diagenetic models and their implementation. Springer-Verlag, Berlin, Heidelberg.

Caffrey, J.M., 1995. Spatial and seasonal patterns in sediment nitrogen remineralisation and ammonium concentrations in San Francisco Bay, California. Estuaries 18, 219-233.

Callender, E., Hammond, D.E., 1982. Nutrient exchanges across the sediment water interface in the Potomac River Estuary. Estuarine Coastal Shelf Sci. 15, 395-413.

Christensen, J.P., Rowe, G.T., 1984. Nitrification and oxygen consumption in northwest Atlantic deep-sea sediments. J. Mar. Res. 42, 1099-1116.

Codispoti, L.A., 1995. Is the ocean losing nitrate? Nature 376, 724-725.

Conan, P., 1996. Variabilité et bilan de la production primaire en zone côtière (Méditerranée nord occidentale, entrée du golfe du Lion) en relation avec les systèmes biologique, chimique et hydrodynamique (courant nord méditerranéen). Thèse de doctorat. Université de Méditerranée, Aix-Marseille.

Conan, P., Pujo-Pay, M., Raimbault, P., Leveau, M., 1998. Variabilité hydrologique et biologique du golfe du Lion. II. Productivité sur le bord interne du courant. Oceanol. Acta 21, 767-782. 
Conley, D.J., Johnstone, R.W., 1995. Biogeochemistry of N, P and Si in Baltic Sea sediments: response to a simulated deposition of a spring diatom bloom. Mar. Ecol. Prog. Ser. 122, 265-276.

Coste, B., Raimbault, P., 1993. Recent data on the nutrient input into the Mediterranean Sea by the Rhône River. In: Martin, J.M., Barth, H. (Eds.), Water pollution research report 30 - EROS 2000. Fourth project workshop, Plymouth. CEC Directorate general for science, research and development, Brussels, pp. 219-224.

Coste, B., Raimbault, P., 1995. Inputs of phosphorus and nitrogen into the Mediterranean Sea by the Rhône River: variability during the last 20 years. Rapp. Comm. Int. Mer Méd. 34, 57.

Cowan, J.L.W., Pennock, J.R., Boynton, W.R., 1996. Seasonal and interannual patterns of sediment-water nutrient and oxygen fluxes in Mobile Bay, Alabama (USA): regulating factors and ecological significance. Mar. Ecol. Prog. Ser. 141, 229-245.

Cruzado, A., 1995. Nutrient distributions in the Gulf of Lions (Northwestern Mediterranean) during cruise RRS Discovery (July 1993). In: Martin, J.M., Barth, H. (Eds.), Water pollution research report 32 - EROS 2000. Fifth project workshop, Hamburg. CEC Directorate general for science, research and development, Brussels, pp. 69-77.

Denis, L., 1999. Dynamique des flux d'oxygène et de sels nutritifs à l'interface eau-sédiment sur la marge continentale du Golfe du Lion (Méditerranée nord occidentale). Thèse de doctorat. Université de Méditerranée, Aix-Marseille.

Devol, A.H., Christensen, J.P., 1993. Benthic fluxes and nitrogen cycling in sediments of the continental margin of the eastern North Pacific. J. Mar. Res. 51, 345-372.

Emerson, S., Jahnke, R., Heggie, D., 1984. Sediment-water exchange in shallow water estuarine sediments. J. Mar. Res. 42, 709-730.

Enoksson, V., Samuelsson, M.O., 1987. Nitrification and dissimilatory ammonium production and their effects on nitrogen flux over the sediment-water interface in bioturbated coastal sediments. Mar. Ecol. Prog. Ser. 36, 181-189.

Ganesham, R.S., Pedersen, T.F., Calvert, S.E., Murray, J.W., 1995. Large changes in oceanic nutrients inventories from glacial to interglacial periods. Nature 376, 755-758.

Gehlen, M., Rabouille, C., Ezat, U., Guidi-Guilvard, L.D., 1997. Drastic changes in deep-sea sediment pore-water composition induced by episodic input of organic matter. Limnol. Oceanogr. 42, 980-986.

Grenz, C., Cloern, J., Hager, S.W., Cole, B.E., 2000. Dynamics of nutrient cycling and related benthic nutrient and oxygen fluxes during a spring phytoplankton bloom in south San Francisco Bay (USA). Mar. Ecol. Prog. Ser. 197, 67-80.

Henriksen, K., Kemp, W.M., 1988. Nitrification in estuarine and coastal marine sediments. In: Blackburn, T.H., Sorensen, J. (Eds.), Nitrogen cycling in coastal marine environments. Wiley and sons, New York, pp. 207-249.

Jensen, M.H., Lomstein, E., Sorensen, J., 1990. Benthic $\mathrm{NH}_{4}{ }^{+}$and $\mathrm{NO}_{3}{ }^{-}$flux following sedimentation of a spring phytoplankton bloom in Aarhus Bight, Denmark. Mar. Ecol. Prog. Ser. 61, 87-96.

Kemp, W.M., Boynton, W.R., 1992. Benthic-pelagic interactions: Nutrients and oxygen dynamics. In: Smith, D.E., Leffler, M.,
Mackiernan, G. (Eds.), Oxygen dynamics in Cheseapeake Bay: a synthesis of recent research. Maryland Sea Grant, College Park, MD, pp. 149-222.

Koop, K., Boynton, W.R., Wulff, F., Carman, R., 1990. Sediment-water oxygen and nutrient exchanges along a depth gradient in the Baltic Sea. Mar. Ecol. Prog. Ser. 63, 65-77.

Mayer, M.S., Schaffner, L., Kemp, W.M., 1995. Nitrification potentials of benthic macrofaunal tubes and burrow walls: effects of sediment $\mathrm{NH}_{4}{ }^{+}$and animal irrigation behaviour. Mar. Ecol. Prog. Ser. 121, 157-169.

Middelburg, J.J., Vlug, T., van der Nat, F.J.W.A., 1993. Organic matter mineralisation in marine systems. Global Planet. Change 8, 47-58.

Millot, C., 1987. Circulation in the Western Mediterranean Sea. Oceanol. Acta 10, 143-149.

Millot, C., 1990. The Gulf of Lions' hydrodynamics. Cont. Shelf Res. 10, 885-894.

Morel, A., André, J.M., 1991. Pigment distribution and primary production in the western Mediterranean as derived and modeled from coastal zone color scanner observations. J. Geophys. Res. 96, 12685-12698.

Nowicki, B.L., Nixon, S.W., 1985. Benthic nutrient remineralisation in a coastal lagoon ecosystem. Estuaries 8, 182-190.

Santschi, P., Höhener, P., Benoit, G., Buchholtz-ten Brink, M., 1990. Chemical processes at the sediment-water interface. Mar. Chem. 30, 269-315.

Soetaert, K., Herman, P.M.J., Middelburg, J.J., 1996. Dynamic response of deep-sea sediments to seasonal variations: a model. Limnol. Oceanogr. 41, 1651-1668.

Solorzano, L., 1969. Determination of ammonia in natural waters by the phenol-hypochlorite method. Limnol. Oceanogr. 14, 799-801.

Tréguer, P., Le Corre, P., 1975. Manuel d'analyses des sels nutritifs dans l'eau de mer: utilisation de l'Autoanalyser II Technicon. Université de Bretagne occidentale, Brest.

Tusseau, M.H., Mouchel, J.M., 1995. Nitrogen inputs to the Gulf of Lions via the Rhône River. In: Martin, J.M., Barth, H. (Eds.), Water pollution research report 32 - EROS 2000. Fifth project workshop, Hamburg. CEC Directorate general for science, research and development, Brussels, pp. 49-60.

Tusseau-Vuillemin, M.H., Mortier, L., Herbaut, C., 1998. Modeling nitrate fluxes in an open coastal environment (Gulf of Lions): Transport versus biogeochemical processes. J. Geophys. Res. 103, 7693-7708.

Ullman, W.J., Aller, R.C., 1982. Diffusion coefficients in nearshore marine sediments. Limnol. Oceanogr. 27, 552-556.

Van Cappellen, P., Wang, Y., 1996. Cycling of iron and manganese in surface sediments: a general theory for the coupled transport and reaction of carbon, oxygen, nitrogen, sulfur, iron, and manganese. Am. J. Sc. 296, 197-243.

Vidal, M., Morgui, J.A., 1995. Short term pore-water ammonium variability coupled to benthic boundary layer dynamics in Alfacs Bay, Spain (Ebro Delta, NW Mediterranean). Mar. Ecol. Prog. Ser. 118, 229-236. 